\title{
TAMBANG RAKYAT, BERKAH ATAU MUSIBAH? (STUDI TENTANG TAMBANG EMAS RAKYAT DI GUNONG UJEUN KABUPATEN ACEH JAYA)
}

\author{
Aminah \\ Fakultas Ilmu Sosial dan Ilmu Politik Universitas Teuku Umar \\ aminahaneukpanga@gmail.com
}

\begin{abstract}
This study aims to explain the gold mining in Gunong Ujeun, Aceh jaya by using the theories of Thomas Homer-Dixon of the environmental scarcity, whether in Gunong Ujeun mining can be categorized as a blessing or a disaster with a view of reality and phenomena that exist in the field. The data in this research was obtained through literature (library research) and field research. The results showed that small-scale gold mining in the region Gunong Ujeun has many benefits, it is a blessing bestowed by the Almighty to the people, especially for people who do the mining. Since 2008 has been a lot of things are changing in the region District of Krueng Sabee, ranging from forests to watersheds in the river. The destruction of the forest will be an impact on other natural resources such as soil cycles are no longer fertile, discoloration and quality of water, as well as damage to the fish that were in the river will die, and as a result of toxic mercury wastes are poured into the river. This caused conflict among the community. It is is a horizontal conflict between migrant and local communities. The cause of it, namely (1) frequent flooding aftermath of the mining (2) more difficult to get fresh fish and the water has been contaminated with mercury and cyanide. (3) government agency that is less concerned with the environment (4) Control of natural resources by immigrant communities.
\end{abstract}

Keywords: Peoples Mining, conflict, environmental degradation. 


\section{PENDAHULUAN}

Negara Republik Indonesia merupakan salah satu negara yang kaya akan akan Sumber Daya Alam (SDA). Kekayaan sumberdaya alam ini merupakan suatu keberkahan sekaligus sebagai karunia Tuhan Yang Maha Esa yang diberikan kepada negara Republik Indonesia ini. Ada beberapa jenis kekayaan alam yang terdapat di negara yang sedang berkembang ini, yaitu kekayaan alam yang dapat diperbaharui (hutan, tanah, lahan subur, air, sungai, laut), dan kekayaan alam yang tidak dapat diperbaharui (minyak bumi, gas, dan bahan tambang lainnya). Menurut Undang-Undang Nomor 11 Tahun 1967, bahan tambang terbagi menjadi tiga Golongan yaitu Golongan A (disebut sebagai bahan strategis), Golongn B (sebagai bahan vital) dan Golongan C (bahan tidak strategis dan tidak vital).

Dalam peraturan pemerintah Nomor 27 Tahun 1980 juga menjelaskan secara rinci bahwa jenis tambang Golongan A adalah barang yang penting bagi pertahanan, keamanan dan strategis untuk menjamin perekonomian negara dan sebagian besar hanya diizinkan untuk dimiliki oleh pemerintah. Contoh Golongan A yaitu Minyak Bumi, Uranium dan plutonium. Sedangkan bahan Golongan B adalah bahan tambang yang dapat menjamin hidup orang banyak. Contohnya adalah Emas, Perak, Besi dan tembaga. Bahan Golongan $\mathrm{C}$ adalah bahan tambang yang tidak dianggap langsung mempengaruhi hayat hidup orang banyak (Peraturan Pemerintah Nomor 27 Tahun 1980). Contoh bahan Golongan C adalah Garam, Pasir, Marmer, Batu Kapur, Tanah Liat dan Asbes.

Dibalik semua keberkahan yang telah Tuhan limpahkan ke perut bumi ini, terdapat berbagai permasalahan di daerah penghasil tambang, baik yang dihadapi oleh masyarakat penambang, masyarakat non-penambang (masyarakat yang tinggal di daerah penambangan akan tetapi tidak melakukan penambangan), pemerintah maupun Aktivis-aktivis anti tambang, yang pada akhirnya dari yang seharusnya berkah berubah menjadi musibah. Permasalahan yang paling sering dihadapi oleh daerah penghasil tambang adalah munculnya konflik, mulai dari konflik laten (konflik yang tidak muncul kepermukaan atau konflik yang tidak berujung terhadap kekerasan) hingga konflik kekerasan yang menjatuhkan korban.

Salah satunya adalah konflik kekerasan yang berkepanjangan yang terjadi di Provinsi Aceh dan Provinsi Papua. Semua konflik yang terjadi di Aceh berawal sejak zaman pemberontakan DI/TII pimpinan Daud Beureuh tahun 1953 hingga Hasan Tiro 1976. Korbankorban yang berjatuhan pun tidak sedikit. Hal ini juga didukung oleh kebijakan negara saat itu yang cenderung mengedepankan pendekatan militer dengan menurunkan ribuan tentara non organik ke wiilayah ini. Pemberontakan yang terjadi oleh Daud Beureuh (Ibrahimy-El, M. Nur, 2001) dilatarbelakangi lebih banyak didorong oleh keinginannya untuk memanifestasikan nilainilai Islam dan sistem pemerintahan Aceh (Rani Usman, 2003:124). Berbeda dengan latar belakang pemberontakan Daud Beureuh, pemberontakan Hasan Tiro lebih dimotivasi oleh nasionalisme Aceh yang tumbuh sejak era kesultanan Aceh melawan penjajahan Belanda dan oleh ketidakadilan yang dirasakan rakyat Aceh, terutama dalam hal pengelolaan sumber daya alam (Djumala, 2003: 5).

Selanjutnya juga pada masa orde baru yang mengeksploitasi sumber daya alam Aceh guna menopang pembangunan nasional. Seperti eksploitasi sumber alam di Aceh dalam bentuk gas dan minyak. Eksploitasi sumber daya alam Aceh didistribusikan kembali ke Aceh hanya sampai 20\% dari pemasukan eksploitasi alam, sedangkan 70\% diambil oleh pemerintah Pusat untuk pembangunan Nasional. Eksploitasi secara besar-besaran serta kurang meperhatikan masyarakat lokalpun tak terhindarkan. Pemberian hak pengelolaan kepada perusahaanperusahaan besar atas hutan Aceh dan pemberian hak eksploitasi atas berbagai sumberdaya alam lainnya (pertambangan Minyak dan Gas) tanpa disertai alokasi yang transparan dan adil, telah menumbuhkan kekecewaan yang semakin mendalam masyarakat Aceh kepada pemerintah Pusat (M. Hamdan dan Basyar, 2006). 
Fakta ini menyebabkan masyarakat Aceh berada di bawah garis kemiskinan, berpendidikan rendah, dan hancurnya identitas lokal. Bumi Aceh pada saat itu, ibarat sapi perahan yang diambil susunya secara terus-menerus, tanpa memperdulikan tubuh dan materialnya. Pemerintah Pusat tidak pernah menanggapi ketidakpuasan masyarakat Aceh secara serius. Akumulasi inilah yang selanjutnya menjadi pemberontakan di Aceh dan melahirkan gerakan pemisahan diri dibawah bendera Acheh Sumatra National Liberation Front (ASNLF) yang kemudian dikenal dengan nama Gerakan Aceh Merdeka (GAM). Namun pada tanggal 15 Agustus 2005 konflik yang berkepanjangan melanda Aceh dapat diredam dengan adanya perdamaian atau Momorandum of Understanding (MoU) atau lebih dikenal dengan sebutan MoU Helsinki.

Berdasarkan nota kesepakatan tersebut dan otonomi khusus yang diberikan RI kepada pemerintah Aceh, pemerintah RI menyetujui bahwa hasil alam yang ada di wilayah Provinsi Aceh baik yang dikelola oleh masyarakat, BUMN, BUMD, Koperasi, maupun investasi luar, pemerintah Aceh berhak mendapatkan dan mengelola hasil sumberdaya alam tersebut sebesar $70 \%$. Tiga puluh persen selanjutnya diserahkan kepada pemerintah pusat. Namun pasca persetujuan nota kesepahaman yang ditandatangani pada tahun 2005 tersebut, potensi-potensi konflik di provinsi Aceh masih mengancam.

Hal yang sama juga terjadi di Papua, konflik di Papua telah dimulai sejak tahun 1949 semenjak penyatuan wilayah papua ke dalam Negara Kesatuan Republik Indonesia (NKRI). Dalam perjanjian penyerahan yang dilakukan di Den Haag tersebut, pemerintah Belanda menyerahkan kedaulatan seluruh teritorial Hindia Belanda, kecuali Papua kepada Pemerintah RI. Sejak itu, Papua mulai melakukan perlawanan untuk memerdekakan Papua. Kelompok ini dinamakan OPM (Organisasi Papua Merdeka). OPM ini lahir semenjak tahun 1960-an. Sekitar tahun 1070-an, setelah Freeport beroperasi mendulang emas dan bahan tambang lainnya, popularitas terhadap OPM dari masyarakat Papua semakin meningkat. Kekuatan konflik di Papua dapat diredam dengan diberikannya Otonomi Khusus oleh pemerintah pusat kepada pemerintah daerah Papua (https://icssis.fies.wordpress.com)

Hampir disetiap wilayah pertambangan tejadi konflik, tidak terkecuali di wilayah Gunong Ujeun Kecamatan Krueng Sabee Kabupaten Aceh Jaya. Gunong Ujeun adalah salah satu lokasi tambang emas yang dikelola oleh masyarakat Kabupaten Aceh Jaya. Letaknya diapit oleh dua kecamatan yaitu Kecamatan Krueng Sabee (Gampong Panggong) dan Kecamatan Panga (Gampong Batee Meutudong). Wilayah pertambangan emas rakyat tersebut ditemukan oleh masyarakat pada tahun 2006 dan mulai diekploitasi secara besar-besaran pada tahun 2008. Wilayah pertambangan emas rakyat tersebut baru mendapatkan rekomendasi dari pihak gubernur untuk dijadikan sebagai Wilayah Pertambangan Rakyat (WPR) seluas 1.000 Ha pada tahun 2014 (Aminah, 2014:37).

Konflik yang terjadi di Wilayah Gunong Ujeun adalah konflik Laten. Dimana konflik yang terjadi tersebut tidak dalam bentuk tindak kekerasan dan tidak adanya gerakan dari masyarakat untuk menghentikan tambang tersebut. Konflik ini terjadi antara masyarakat pendatang dengan masyarakat lokal. Bentuk konflik yang terjadi di wilayah Gunong Ujeun adalah konflik laten. Dimana dalam konflik ini tidak terlihat adanya konflik yang besar seperti tindak kekerasan dan lain sebagainya. (Aminah, 2015:100). Masyarakat yang datang dari berbagai daerah juga melakukan penambangan di wilayah Gunong Ujeun baik yang sudah bergabung dengan koperasi-koperasi yang telah dibentuk di kecamatan Panga dan kecamatan Krueng Sabee maupun sebagai penambang perorangan yang melakukan penambangan secara tradisional di wilayah tersebut. Hal ini tentu saja akan menimbulkan konflik diantara masyarakat pendatang dengan masyarakat lokal.

Berdasarkan permasalahan diatas, tulisan ini mencoba untuk menganalisis apakah pertambangan emas rakyat yang ada di Gunong Ujeun Kabupaten Aceh Jaya dapat dikategorikan sebagai Berkah atau Musibah dengan melihat realitas yang ada dilapangan. 


\section{KAJIAN LITERATURE}

Teori yang dipakai dalam penelitian ini adalah teori Kelangkaan Lingkungan (environmental scarcity) konsep dari Thomas Homer-Dixon. Homer-Dixon sangat dikenal dengan penelitian tentang hubungan lingkungan, kelangkaan dan kekerasan. Melalui penelitiannya, Homer berusaha membuat suatu gambaran yang lebih jelas kaitan antara tekanan lingkungan dan munculnya kekerasan. Dimana tekanan lingkungan yang disebut "kelangkaan lingkungan" berkontribusi terhadap kerusakan sosial dan kekerasan. Koneksi antara kelangkaan lingkungan dan kekerasan dianalisisnya secara rumit (Homer-Dixon, 1991:2).

Menurut Homer-Dixon, peperangan masa depan dan kekerasan sipil akan sering muncul karena kelangkaan sumber daya seperti air, tanah pertanian, hutan dan ikan. Negara-negara yang basis sumberdaya alamnya terancam merosot akan melakukan perlawanan yang menyebabkan munculnya konflik kekerasan (Samuel P, Hantington, 2005:117). Dalam penelitiannya, HomerDixon memfokuskan pada sumberdaya yang dapat diperbarui (renewable resources). Dalam penelitian tersebut Homer-Dixon (Homer-Dixon and Percival, 1996:12) mengajukan dua pertanyaan penelitian untuk mencari dan menjelaskan hubungan kausalitas antara kelangkaan lingkungan dan konflik sosial. Pertama, apakah kelangkaan lingkungan dapat menghasilkan kekerasan di negara berkembang?. Kedua, implikasinya, bagaimana hubungan antara keduanya?. Hubungan kausalitas antara kelangkaan lingkungan dan konflik kekerasan tidak akan menjelma menjadi konflik ketika institusi politik mampu memainkan perannya dengan baik. Jika faktor-faktor personal, institucional dan struktural ini berinteraksi dengan faktor sosial lainnya maka akan memiliki kekuatan baru untuk menimbulkan konflik kekerasan (HomerDixon, 1999; Homer-Dixon 1998; Schwartz, Deligianis \& Homer-Dixon, 2000). Konflik dan ketegangan sosial tidak terjadi dengan sendirinya. Untuk lebih jelas perhatikan gambar berikut:

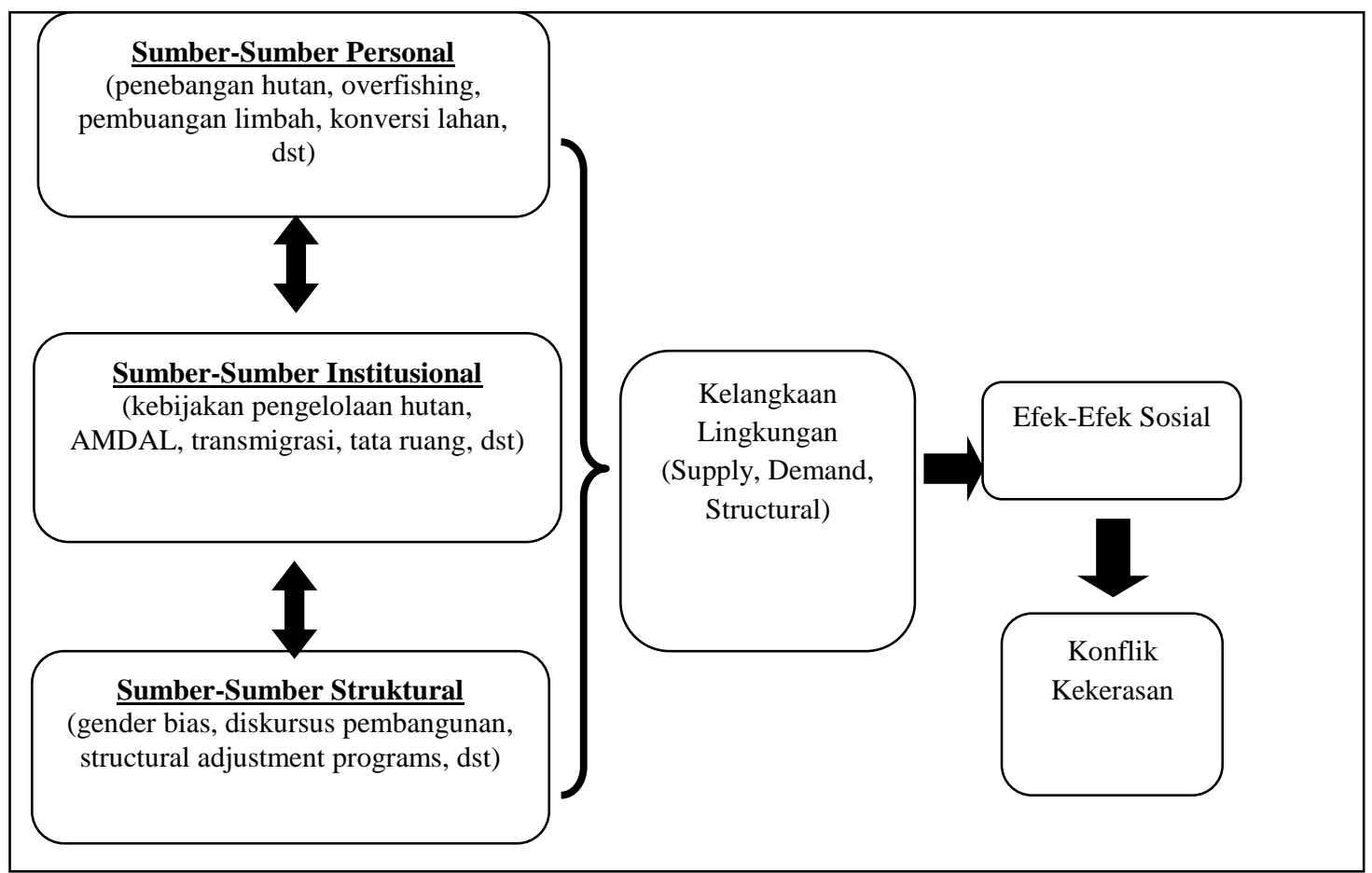

Gambar I. Penyebab Konflik dan Ketegangan Sosial dalam Kelangkaan Lingkungan Dari Homer-Dixon.

Sumber: Analisis Penulis 
Dari gambar diatas dapat dilihat bahwa konflik kekerasan atau ketegangan sosial tidak terjadi dengan sendirinya. Namun ketika kelangkaan lingkungan tersebut berinteraksi dengan sumber-sumber konflik yang lain yang bersumber dari sumber-sumber personal yang terdiri dari (penebangan hutan, overvising, pembuangan limbah, konservasi lahan), sumber institusional yang terdiri dari kebijakan pengelolaan hutan, AMDAL, transmigrasi, tata ruang dst) serta struktural (Gender bias, diskursus pembangunan, structural adjustment programs dst) yang bersifat suplply, demand dan struktural maka akan menimbulkan efek-efek sosial. Dari efekefek sosial tersebut, maka akan menimbulkan konflik kekerasan atau ketegangan sosial. HomerDixon menjelaskan bahwa kelangkaan lingkungan disebabkan oleh tiga hal yaitu dari sisi permintaan, sisi penawaran, dan sisi struktural (Lihat Gambar II).

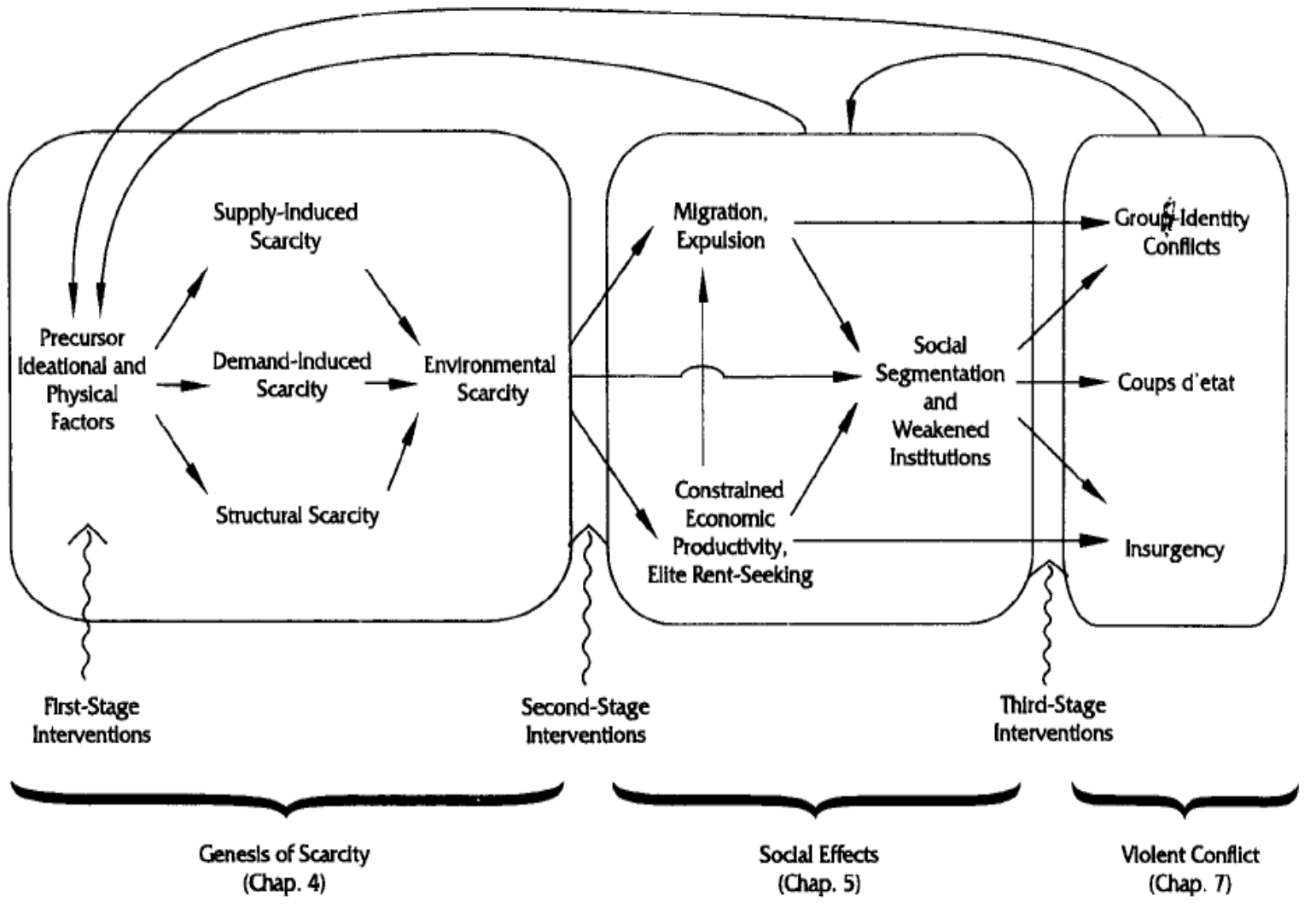

Gambar II. Siklus Konflik Kelangkaan Lingkungan

Kelangkaan lingkungan (environmental scarcity) terjadi ketika kejadian-kejadian alam dan faktor-faktor fisik lainnya berinteraksi dengan faktor permintaan, penawaran, dan struktural. Akibat dari interaksi ini adalah berkurangnya produktivitas, lingkungan akibat bencana dan eksploitasi berlebihan, meningkatnya permintaan atas sumberdaya karena peningkatan konsumsi dan jumlah penduduk, dan ketidakadilan distribusi sumberdaya. Supply-induced scarcity terjadi ketika sumberdaya alam berkurang secara perlahan atau drastis akibat eksploitasi yang berlebihan sehingga ketersediaan sumberdaya di bumi semakin menipis. Demand-induced scarcity disebabkan oleh bertambahnya permintaan atas sumberdaya alam. Pertambahan ini disebabkan adanya peningkatan konsumsi seperti pertumbuhan penduduk, pertumbuhan di sektor industri, dan pembangunan ekonomi. Sementara, structural-induced scarcity disebabkan oleh ketimpangan pendapatan, kekuatan ekonomi, ataupun ketidakadilan dalam mendistribusikan sumberdaya alam. Pada konteks ini, sebagian besar sumberdaya 
terkonsentrasi atau dikuasai oleh sekelompok kecil penduduk, sementara porsi terbesar penduduk mengalami kekurangan (Ucu Martanto, :9-10).

Dalam risetnya, Homer-Dixon kemudian mengembangkan teori kerusakan lingkungan dan kelangkaan sumber daya alam, termasuk pangan, sebagai pemicu munculnya konflikkonflik yang brutal (Homer-Dixon and Jessic Blitt, 1991: 71). Menurut Homer-Dixon biang dari seluruh permasalahan lingkungan adalah kelangkaan sumberdaya alam yang terbaharukan dan yang menjadi penyebab utama terjadinya kelangkaan sumberdaya adalah pertumbuhan penduduk yang cepat. Hal inilah yang menurut Homer-Dixon menjadi penjelas mengapa konflik atas lingkungan lebih sering terjadi di negara-negara berkembang yang pertumbuhan penduduknya yang tinggi daripada negara-negara maju yang pertumbuhan penduduknya rendah.

Homer-Dixon (1991:71) ingin menunjukkan bahwa pemenuhan kebutuhan manusia berkaitan erat dengan pergeseran kualitas serta kuantitas lingkungan. Konflik sosial akan muncul ketika tidak ada lagi keseimbangan antara jumlah yang dibutuhkan dengan yang didapatkan. Homer-Dixon menyimpulkan bahwa "Saat Kerusakan lingkungan berlanjut, besarnya gejolak sosial juga akan meningkat. Homer-Dixon juga menyatakan bahwa konflik, damai dan ketegangan yang terjadi dalam masyarakat tergantung kondisi lingkungan dan pendekatan ekonomi politik yang dilakukan di suatu negara. Pengelolaan sumber daya alam secara sentralistik rentan menyebabkan konflik, sedangkan desentralisasi mampu mengurangi resiko konflik.

\section{METODOLOGI PENELITIAN}

Metode penelitian yang digunakan dalam penelitian adalah metode penelitian kualitatif dengan pendekatan studi kasus. Adapun yang menjadi lokasi penelitian ini adalah Gunong Ujeun Kecamatan Krueng Sabee Kabupaten Aceh Jaya, Provinsi Aceh, dengan pertimbangan bahwa, lokasi tersebut merupakan salah satu tempat yang memiliki kekayaan tambang berupa pertambangan emas yang merupakan salah satu keberkahan yang Tuhan berikan untuk dimanfaatkan oleh manusia agar dapat meningkatkan tarap kehidupan masyarakat.

Teknik pengumpulan data dilakukan melalui kepustakaan dan lapangan. Kepustakaan dengan membaca buku teks dan bahan bacaan lainnya yang berkaitan dengan tema penelitian sedangkan lapangan dengan mewawancarai para informan yang menjadi sumber informasi bagi penulis untuk menganalisis dengan menggunakan teori yang digunakan. Yang menjadi informan dalam penelitian ini adalah Kasie Pengusahaan Pertambangan Mineral Batubara dan Panas Bumi Dinas Pertambangan dan Energi Aceh, Kepala Bidang Pertambangan, Energi, dan Sumber Daya Mineral Kabupaten Aceh Jaya, Ketua Dewan Perwakilan Rakyat Kabupaten (DPRK) Aceh Jaya, Anggota DPRK Aceh Jaya Komisi C bidang Pertambangan, Pihak Kecamatan Krueng Sabee, pihak kecamatan Panga, Kepala Desa (Geuchik) Gampong Batee Meutudong, Kepala Desa (Geuchik) Gampong Panggong, Anggota Koperasi pertambangan rakyat (pendatang dan masyarakat lokal), Masyarakat penambang perseorangan (pendatang dan masyarakat lokal), Ketua Koperasi Pertambangan Rakyat Peusahoe Rakan di Kecamatan Krueng Sabee, Ketua Koperasi Pertambangan Rakyat Aceh Sumatra di Kecamatan Panga. Sedangkan teknik analisis data yaitu Proses analisis data dimulai dengan menelaah seluruh data yang tersedia dari berbagai sumber, setelah menelaah langkah berikutnya yaitu mereduksi data dengan melakukan abstraksi atau membuat rangkuman inti. Tahap ketiga yaitu menyusun datadata tersebut dalam satuan-satuan dan tahap akhir dari analisis data ialah melakukan pemeriksaan keabsahan data (Moleong, 2002: 247).

\section{HASIL PENELITIAN DAN PEMBAHASAN}

Pertambangan emas rakyat ada di wilayah Gunong Ujeun kabupaten Aceh Jaya memiliki banyak manfaat, ini merupakan suatu keberkahan yang dianugerahkan oleh yang Maha Kuasa kepada masyarakat, terutama bagi masyarakat yang melakukan penambangan. Hal ini 
menyebabkan terjadinya pengekploitasian tambang emas semakin lama semakin marak dilakukan. Banyak masyarakat yang datang dari berbagai daerah ke lokasi Gunong Ujeun untuk bekerja sebagai penambang terutama dari wilayah pulau Jawa (Bogor) dan kabupaten/kota lainnya baik yang bergabung dengan koperasi yang ada di kecamatan Panga dan Kecamatan Krueng Sabee maupun bekerja secara individu (tidak bergabung dengan Koperasi). Namun meskipun Kabupaten Aceh Jaya memiliki kekayaan alam yang dianugerahkan oleh Yang Maha Kuasa yang beraneka ragam terutama emas yang harga jualnya tinggi namun sampai saat ini pemerintah kabupaten Aceh Jaya belum menerima pendapatan asli daerah dari hasil tambang emas tersebut (Aminah, 2016:137).

Sejak tahun 2008 proses eksploitasi pertambangan emas rakyat di Gunong Ujeun mulai dilakukan secara besar-besaran, telah banyak hal yang berubah diwilayah Kecamatan Krueng Sabee, mulai dari tatanan hutan hingga aliran sungai Krueng Sabee. Rusaknya hutan tersebut akan berdampak kepada sumberdaya alam lainnya seperti siklus tanah sudah tidak subur lagi, perubahan warna air dan kualitas air, serta kerusakan terhadap ikan-ikan yang berada disungai akan mati serta beracun akibat limbah merkuri yang dialirkan ke sungai Krueng Sabee Aceh Jaya. Penambangan emas di Gunong Ujeun, bisa dianggap sebagai suatu berkah sekaligus juga sebagai musibah bagi masyarakat sekitar. Bagi masyarakat penambang mereka mendapatkan hasil tambang yang banyak bahkan beberapa diantara mereka telah menjadi orang terkaya saat ini di kabupaten Aceh Jaya. Namun disisi lain, masyarakat yang tidak menambang akan mendapat musibah baik itu banjir maupun sulit dalam mendapatkan air serta ikan segar seperti dulu.



\section{Gambar III. Kondisi Pertambangan Emas Gunong Ujeun Kabupaten Aceh Jaya}

Berdasarkan gambar diatas dapat dilihat bahwa wilayah pertambangan emas yang dulunya merupakan wilayah hutan produksi telah berubah menjadi wilayah yang gundul serta banyaknya lobang-lobang yang telah digali oleh masyarakat. Masyarakat yang berada di wilayah pertambangan terutama masyarakat yang masih menggunakan air bersih dari aliran sungai Krueng Sabee akan merasa takut dan was-was terhadap air yang digunakan tersebut. Hal ini dikeranakan pihak Dinas Kesehatan Kabupaten Aceh Jaya telah melakukan tes terhadap air sungai Krueng Sabee. Berdasarkan hasil tes yang dilakukan oleh Dinas Kesehatan Kabupaten Aceh Jaya bahwa air yang mengalir di sungai Krueng Sabee dan beberapa sumur masyarakat yang berdekatan dengan gelondongan (tempat penggilingan emas) telah tercemar oleh mercury (zat kimia yang beracun). Mercury tersebut digunakan oleh masyarakat penambangan emas untuk memisahkan antara emas dan bebatuan.

Apabila pemerintah Kabupaten Aceh Jaya kurang melakukan pengawasan terhadap proses penambangan emas rakyat di Gunong Ujeun maka dikhawatirkan akan muncul benih-benih konflik dalam masyarakat terutama antara masyarakat pendatang dengan masyarakat lokal. Homer-Dixon (1991:134), menjelaskan bahwa penyebab konflik dan ketegangan sosial dalam 
kelangkaan lingkungan tidak dapat terjadi dengan sendirinya. Namun ketika kelangkaan lingkungan tersebut berinteraksi dengan sumber-sumber konflik lainnya yang bersumber dari sumber personal (penebangan hutan, overfishing, pembuangan limbah, konversi lahan, dst), sumber institusional (kebijakan pengelolaan hutan, AMDAL, transmigrasi, tata ruang, dst) dan sumber struktural (gender bias, diskursus pembangunan, structural adjustment programs, dst) yang juga bersifat supply, demand, dan struktural, maka sumber-sumber inilah yang akan menimbulkan konflik dan ketegangan sosial.

Dari hasil penelitian dilapangan mengungkapkan dalam proses penambangan emas rakyat di wilayah Gunong Ujeun Kabupaten Aceh Jaya telah terjadi konflik bersifat laten. Konflik tersebut terjadi antara masyarakat pendatang dengan masyarakat lokal. Penyebab terjadinya konflik di wilayah pertambangan yaitu pertama masyarakat Kecamatan Krueng Sabee sering dilanda banjir pasca terjadinya penambangan emas rakyat di Gunong Ujeun. kedua masyarakat Kecamatan Krueng Sabee semakin sulit untuk mendapatkan ikan-ikan segar dan air bersih karena ikan dan air telah terkontaminasi dengan mercury dan sianida. Penyebaran merkuri ini menyebabkan masyarakat mengalami kelangkaan sumber air yang bersih dan ikan-ikan serta kerang tidak dapat dimakan lagi sehingga terjadi konflik antara masyarakat penambang dengan masyarakat lokal yang masih menggunakan air sungai Krueng Sabee sebagai sumber kehidupan bagi masyarakat kecamatan Krueng Sabee. Ketiga lembaga pemerintah yang kurang peduli dengan lingkungannya, meskipun Pemerintah kabupaten Aceh Jaya telah mendapatkan rekomendasi dari Gubernur Aceh pada tahun 2010 serta mengeluarkan Peraturan Bupati (Perbup) Aceh Jaya Nomor 21 Tahun 2011 tentang Penataan Pertambangan Rakyat. Namun fakta dilapangan bahwa peraturan tersebut belum berjalan secara optimal. Keempat adanya penguasaan sumberdaya alam oleh masyarakat pendatang terhadap wilayah pertambangan. Hal ini terlihat bahwa hampir 65 persen masyarakat yang melakukan penambangan emas rakyat diwilayah Gunong Ujeun adalah masyarakat pendatang. Sementara masyarakat lokal akan merasa terjajah dengan kehadiran mereka dilingkungannya. Sebagai konsekuensinya, keamanan lingkungan yang terganggu akan memicu terjadinya masalah keamanan lainnya. Seperti keamanan pangan yang pada akhirnya akan menyebabkan keamanan individu masyarakat lokal di wilayah Gunong Ujeun.

Dari beberapa penyebab konflik diatas, jika saling berinteraksi antara satu penyebab dengan penyebab lainnya akan menyebabkan kelangkaan lingkungan yang nantinya juga akan berujung pada tindak kekerasan (konflik kekerasan). Untuk menghindari dampak negatif dari kelangkaan lingkungan ini, pemerintah kabupaten Aceh Jaya beserta seluruh jajarannya mulai dari pihak dinas-dinas terkait hingga pihak kepolisian harus lebih memperhatikan aspek lingkungan dan masyarakat sekitar wilayah pertambangan emas rakyat di Gunong Ujeun. Hal ini untuk menghindari terjadinya konflik sosial didalam masyarakat.

\section{SIMPULAN DAN SARAN}

\section{A. SIMPULAN}

Pertambangan emas yang ada di wilayah Gunong Ujeun Kecamatan Krueng Sabee Kabupaten Aceh Jaya merupakan salah satu keberkahan yang diberikan oleh Yang Maha Kuasa untuk dipergunakan demi kepentingan hidup masyarakat Kabupaten Aceh Jaya. Namun dalam proses eksploitasi pertambangan emas rakyat di Gunong Ujeun telah menimbulkan konflik sosial yang bisa disebutkan sebagai suatu musibah di dalam masyarakat, Konflik yang terjadi adalah konflik yang bersifat laten secara horizontal yaitu antara masyarakat penambang pendatang dengan masyarakat lokal. Dalam konflik ini telah memperlihatkan bahwa adanya hubungan antara kelangkaan lingkungan dengan konflik dan ketegangan sosial yang terjadi di antara masyarakat penambang pendatang dengan masyarakat lokal di wilayah pertambangan emas rakyat Gunong Ujeun. Namun dalam kasus ini tidak sepenuhnya seperti apa yang 
dibayangkan oleh Homer-Dixon bahwa kelangkaan lingkungan menimbulkan konflik kekerasan. Konflik yang terjadi di wilayah Gunong Ujeun adalah konflik yang bersifat laten.

\section{B. SARAN}

Pertama, Pemerintah Kabupaten Aceh Jaya harus bekerja lebih maksimal dalam pengelolaaan pertambangan emas rakyat dengan mengambil tindakan yang tegas dalam mengelola hasil tambang rakyat tersebut. Agar tidak terjadi konflik di dalam masyarakat. pemerintah kabupaten Aceh Jaya juga harus sering mengunjungi tempat pengolahan pertambangan emas rakyat. Sehingga proses penambangan emas rakyat selalu terkontrol oleh pihak pemerintah. Hal ini akan dapat meminimalisir terjadinya kejahatan atau kecurangan yang dilakukan oleh pihak penambang dilapangan. Selain itu, pemerintah juga harus terus memantau terkait pembuangan limbah Terutama tempat gelondongan yang menggunakan merkuri dan sianida. Sehingga air, tanah dan ikan akan tetap terjaga dan masyarakat tidak perlu takut untuk mengkonsumsikannya. Kedua, Untuk kedepannya disarankan kepada pihak koperasi-koperasi dan pihak individual yang bekerja di wilayah pertambangan emas rakyat baik masyarakat lokal maupun masyarakat pendatang agar memperhatikan lingkungan dalam proses melakukan penambangan emas rakyat di Gunong Ujeun. Dengan memperhatikan lingkungan maka hasil alam tetap bisa diambil dana lam akan terjaga. Sehingga berkah tidak menjadi musibah. pertambangan rakyat agar lebih maksimal dalam melakukan mediasi konflik. Meskipun konflik saat ini masih dalam bentuk konflik laten, namun jika tidak dapat diatasi dengan baik akan menjelma menjadi konflik kekerasan.

\section{REFERENSI}

Aminah. 2014. Kebijakan Pemerintah Aceh Jaya dalam Pengelolaan Tambang Emas Rakyat (Studi Kasus Pertambangan Emas di Kecamatan Krueng Sabee). Skripsi. Fakultas Ilmu Sosial dan Ilmu Politik Universitas Syiah Kuala, Banda Aceh.

Aminah, 2015. Politik Pertambangan Emas Rakyat (Studi Kasus Konflik Pertambangan Emas Di Gunong Ujeun Aceh Jaya). Tesis.. Fakultas Ilmu Sosial dan Ilmu Politik Universitas Airlangga, Surabaya.

Aminah. 2016. Kebijakan Pemerintah Kabupaten Aceh Jaya dalam Pengelolaan Tambang Emas Rakyat Di Gunong Ujeun. Jurnal Public Policy. 2 (2): 137

Basyar, M.H dkk. 2006. Aceh Baru: Tantangan Perdamaian dan Reintegrasi, Yogyakarta: Pusat Penelitian Politik-LIPI.

Djumala, Darmasjah. 2013. Shoft Power Untuk Aceh: Resolusi Konflik dan Politik Desentralisasi, Jakarta: PT. Gramedia Pustaka Utama.

Hantington, Samuel P. 2005. Amerika dan Dunia: Memperdebatkan Bentuk Baru Politik Internasional, Jakarta: Yayasan Obor Indonesia.

Homer-Dixon, T. F dan Jessic Blitt, 1991, Evidence: Links Among Environment, Population and Scarcity, New York: Rowman and Littlefield.

Homer-Dixon, T. 1991. On the Threshold: Environmental Changes as Causes of Acute Conflict. Journal International Security. 16 (2) (Fall).

Homer-Dixon, T. 1999. Environment, Scarcity. Violence. Princeton University Press: New Jersey.

Ibrahimy-El, M. Nur. 2001. Peranan Teungku M. Daud Beureueh dalam Pergelokan Aceh. Media Dakwah.

Martanto, Ucu, "Perubahan Lingkungan dan Konflik Kekerasan: Membaca Papua Melalui Pendekatan Environmental Security”,Laporan Penelitian,Yogyakarta: Universitas Gajah Mada.

Martanto, Ucu. 2009. Paper Seminar International, "Center for Peace and Conflict Resolution", 12 Novermber 2009, Syiah Kuala University, Banda Aceh, Indonesia. Hal: 8. 
Moleong Y. 2002. Metodologi Penelitian Kualitatif Edisi Revisi, Bandung; PT. Remaja Rosdakarya.

Rani, U.A. 2003. Sejarah Peradaban Aceh, Jakarta: Yayasan Obor Indonesia.

Nomensen. 2013. Mereduksi Konflik Vertikal dan Horizontal Di Papua. https://icssis.fies.wordpress.com/2013-02-14.pdf. Diakses tanggal

\section{Peraturan Perundang-Undangan}

Undang-Undang Republik Indonesia Nomor 11 Tahun 2006 Tentang Pemerintahan Aceh Undang-Undang Nomor 11 Tahun 1967 Tentang ketentuan-ketentuan pokok pertambangan peraturan pemerintah Nomor 27 Tahun 1980

Qanun Provinsi Nanggroe Aceh Darussalam Nomor 12 Tahun 2002 Tentang Pertambangan Umum, Minyak dan Gas Alam.

Peraturan Bupati Aceh Jaya Nomor 21 Tahun 2011 tentang Penataan Pertambangan Rakyat 